\title{
Haemodynamic effects of selective beta-adrenergic blockade during acute stage of myocardial infarction
}

\author{
A. Epois, P. Rocha, G. Roudy, J. Bardet, J. P. Bourdarias, and A. Mathivat \\ From the Department of Cardiology, Hópital Ambroise Paré, C.H.U. Paris-Ouest, \\ 9 Avenue Charles de Gaulle, 92-Boulogne, France
}

The haemodynamic effect of practolol, a cardioselective beta-adrenergic receptor blocker, has been studied in 18 patients during the acute phase of myocardial infarction. After intravenous administration of 10 or $20 \mathrm{mg}$, a negative chronotropic effect was observed which was associated with a moderate decrease in cardiac output but no change in stroke volume.

Left ventricular work, ejection time, tension-time index per beat, aortic $d p / d t$, mean pulmonary arterial pressure, and pulmonary and peripheral resistance remained unchanged.

Practolol has an important advantage over propranolol when used in patients with myocardial infarction.

As a result of experimental studies, Lands $e t$ al. (1967) have modified the classification proposed by Ahlquist (1948) to the effect that beta-adrenergic receptors do not constitute a homogeneous group and in order to account for certain experimental observations it is necessary to distinguish between beta-I receptors that subserve lipolysis and the myocardium and beta-2 receptors that subserve bronchodilatation and peripheral vasodilatation.

Experimental studies have shown that practolol is capable of selectively blocking the inotropic and chronotropic effects of catecholamines (Parratt and Wadsworth, 1969, 1970), that is, it can selectively act on the beta-adrenergic myocardial receptors. It does not block the beta-2 receptor nor does it inhibit peripheral and coronary vasodilatation induced by isoprenaline (Ross and Jorgensen, 1970; Bussmann, Rauh, and Krayenbuehl, 1970; Dunlop and Shanks, 1968).

The remarkable antiarrhythmic properties of beta-adrenergic receptor blocking agents are well known and they have potential uses in the treatment of ventricular and supraventricular disturbances during the acute phase of myocardial infarction whenever these disturbances are associated with catecholamine release (Ceremuzynski, StaszewskaBarczak, and Herbaczynska-Cedro, 1969; Richardson, 1963; Han, 1969). However, the

Received 14 December 1971. use of propranolol during the acute stage of myocardial infarction is restricted on account of its depressant effects on myocardial function.

Experimental (Ceremuzynski et al., I969; Dunlop and Shanks, 1968) and human (Gibson, Hoy, and Sowton, 1970; Jewitt, Mercer, and Shillingford, I969) studies have shown that practolol is an effective antiarrhythmic agent in protecting the heart from ventricular and supraventricular disturbances at doses of 5 to $25 \mathrm{mg}$ without any noticeable side effects (Sowton et al., 1968; Jewitt et al., 1969).

This study was designed to investigate the haemodynamic effects of practolol during acute myocardial infarction and to evaluate its potential in the treatment of dysrhythmias.

\section{Patients and methods}

The haemodynamic effects of practolol were studied in 18 patients who had sustained acute myocardial infarctions within the previous 72 hours. The diagnosis of infarction was made in all cases from a typical clinical history, a $Q$ wave indicating necrosis, and a clear rise in serum enzyme levels. In all patients pain had disappeared before catheterization. All the patients were of a physical and mental state to understand the nature of the investigation and all of them assented to take part in the study.

Patients with sinus bradycardia lower than 60 or with atrioventricular block or those in a state of shock were excluded from the study. On the other hand, 6 patients presenting signs of left 
ventricular insufficiency (gallop rhythm, crepitation, and/or radiological signs of pulmonary oedema) were included. The ages of the patients ranged from 32 to 80 years, with an average of 59; there were 12 men and 6 women. Of the 18 patients, 5 had anteroseptal infarctions, 2 had anterior massive infarctions, to had posterior infarctions, and I had a deep septal infarction.

As a general rule no drugs were administered for several hours before the investigation apart from a continuous heparin infusion. During the study patients were examined in the supine position using a pillow and did not receive oxygen.

All patients were submitted to right and left catheterization without premedication. A Cournand $6 \mathrm{~F}$ or $7 \mathrm{~F}$ catheter was inserted percutaneously and passed through the right heart and into the pulmonary artery. A Kifa catheter was advanced to the aortic arch using the Seldinger technique. Pulmonary arterial, right atrial, and aortic pressures were measured with a Statham SP 37 strain gauge and recorded directly on an Elema EM 34 recorder. The reference level was taken halfway between the sternal angle and the level of the examination table. Mean pressures were obtained by electronic integration and the first derivative of aortic pressure was calculated by a differentiator (Elema EMT 44) and used as an index of contractility, since a close correlation exists between the aortic $\mathrm{dp} / \mathrm{dt}$ and the left ventricular dp/dt (George, Taylor, and Ramsay, r967).

Cardiac output was measured by an indicator dilution technique. Five $\mathrm{mg}$ indocyanine green were injected into the pulmonary artery and arterial blood was withdrawn with a constant rate pump (Harvard apparatus).

The systolic ejection time was calculated from a trace of aortic pressure taken at high speed $(100 \mathrm{~mm} / \mathrm{sec}$ ) and the mean systolic pressure was obtained from measuring the area under the trace during the same period.

Using these methods the following parameters have been calculated:

- Stroke work index $\left(\mathrm{g} \mathrm{m} /\right.$ beat $\left./ \mathrm{m}^{2}\right)$

$\mathrm{W} /$ beat $=(\mathrm{PsAo}-\mathrm{PAPd}) \times \mathrm{SI} \times \mathrm{I} \cdot 36 \times \mathrm{I} \cdot 05 /$ 1000

- External work index per minute $(\mathrm{g} \mathrm{m} / \mathrm{min} /$ $\mathrm{m}^{2}$ )

$\mathrm{W} / \mathrm{min}=\mathrm{W} /$ beat $\times \mathrm{HR}$
- Mean systolic ejection rate $\left(\mathrm{ml} / \mathrm{sec} / \mathrm{m}^{2}\right)$

MSER = SI $/ E T$

- Tension time index

per beat (mmHg sec/beat): TTI/beat $=$ PsAo $\times$ ET

per minute $(\mathrm{mmHg} \mathrm{sec} / \mathrm{min}): \mathrm{TTL} /$ beat $\times$ HR

- Peripheral vascular resistances (dynes sec $\mathrm{cm}^{-5}$ ): (PAO-POD) 80/CO

- Pulmonary vascular resistances: (PAPPAPd) $80 / \mathrm{CO}$, where PAO, PAP, PAPd, POD represent mean aortic, mean pulmonary arterial, pulmonary arterial diastolic, and right atrial pressures $(\mathrm{mmHg})$ and PsAo represents the mean systolic aortic pressures, $\mathrm{SI}$ : stroke index (ml/beat/ $\mathrm{m}^{2}$ ), HR: heart rate (beat/min), ET: ejection time (sec), CO: cardiac output (1./min).

Blood samples were taken from the aorta, the pulmonary artery and, in 5 patients, from the coronary sinus. Arterial $\mathrm{O}_{2}$ and $\mathrm{CO}_{2}$ partial pressures and $p \mathrm{H}$ were recorded with an IL Meter. The blood oxygen capacity was measured by the Van Slyke and Neill technique.

In all patients, pressure, blood flow, and blood gas measurements were taken during a control period and then ro minutes after injection of ro $\mathrm{mg}$ practolol into the pulmonary artery and 20 minutes after a further injection of ro $\mathrm{mg}$.

The difference between the control values and these recorded after administration of the drug were compared using Student's $t$ test for paired samples.

\section{Results}

All the results (mean + SEM) are presented in Tables I, 2, 3, and 4. Heart rate fell from a mean of $80.8 \pm 3.8$ to $72.9 \pm 2.9$ beats a minute ro minutes after administration of ro mg practolol, representing a 9 per cent $(\mathrm{P}<0.00 \mathrm{I})$ reduction (Fig. I). After the administration of $20 \mathrm{mg}$ the heart rate remained unchanged. There was a positive correlation between the control values for heart rate and the percentage reduction of heart rate $(\mathbf{r}=0.63)$. Cardiac index fell slightly from $2.77 \pm 0.151 . / \mathrm{min} / \mathrm{m}^{2}$ to $2.48 \pm 0.151 . / \mathrm{min} / \mathrm{m}^{2}$ $(\mathrm{P}<0.0 \mathrm{I})$ though injection of a further ro $\mathrm{mg}$ did not cause any additional reduction (final

TABLE I Haemodynamic data before and after practolol, ro and $20 \mathrm{mg}$

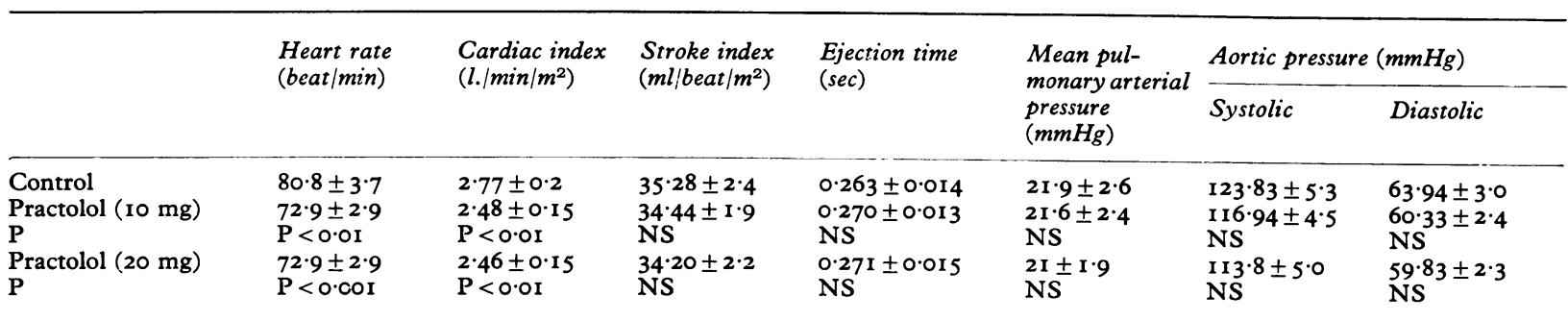

NS, not significant. 
TABLE 2 Haemodynamic data before and after practolol, $10 \mathrm{mg}$ and $20 \mathrm{mg}$

\begin{tabular}{|c|c|c|c|c|c|c|}
\hline & $\begin{array}{l}\text { Stroke work } \\
\text { index } \\
\left(\mathrm{g} \mathrm{m} / \text { beat } / \mathrm{m}^{2}\right)\end{array}$ & $\begin{array}{l}L V \text { minute } \\
\text { work } \\
\left(\mathrm{g} \mathrm{m} / \mathrm{min} / \mathrm{m}^{2}\right)\end{array}$ & $\begin{array}{l}d p / d t A o \\
(m m H g / s e c)\end{array}$ & $\begin{array}{l}\text { Tension time } \\
\text { index/beat } \\
(\mathrm{mmHg} / \mathrm{sec})\end{array}$ & $\begin{array}{l}\text { Tension time } \\
\text { index } / \mathrm{min} \\
(\mathrm{mmHg} / \mathrm{sec} / \mathrm{min})\end{array}$ & $\begin{array}{l}\text { Mean sys- } \\
\text { tolic ejection } \\
\text { rate } / \mathrm{m}^{2} \\
\left(\mathrm{ml} / \mathrm{sec} / \mathrm{m}^{2}\right)\end{array}$ \\
\hline $\begin{array}{l}\text { Control } \\
\text { Practolol (10 mg) } \\
\text { P } \\
\text { Practolol (20 mg) } \\
\text { P }\end{array}$ & $\begin{array}{l}53 \cdot 9 \pm 4 \cdot 9 \\
50 \cdot 4 \pm 4 \cdot 2 \\
\text { NS } \\
49 \cdot 9 \pm 4 \cdot 7 \\
\text { NS }\end{array}$ & $\begin{array}{l}4239 \pm 360 \\
3689 \pm 297 \\
P<0.01 \\
3569 \pm 302 \\
P<0.02\end{array}$ & $\begin{array}{l}905 \pm 88 \\
818 \pm 82 \\
P<0.05 \\
798 \pm 80 \\
P<0.05\end{array}$ & $\begin{array}{l}29 \cdot 2 \pm I \cdot 7 \\
28 \cdot 3 \pm I \cdot 4 \\
\mathrm{NS} \\
27 \cdot 7 \pm I \cdot 4 \\
\mathrm{NS}\end{array}$ & $\begin{array}{l}2307 \pm 142 \\
2094 \pm I 13 \\
P<0.05 \\
1987 \pm 88 \\
P<0.05\end{array}$ & $\begin{array}{l}139 \cdot 8 \pm 11 \cdot 6 \\
138 \cdot 2 \pm 11 \cdot 4 \\
\text { NS } \\
138 \cdot 4 \pm 12 \cdot 6 \\
\text { NS }\end{array}$ \\
\hline
\end{tabular}

NS, not significant.

TABLE 3 Blood gases before and after $10 \mathrm{mg}$ and $20 \mathrm{mg}$ practolol

\begin{tabular}{|c|c|c|c|c|c|c|c|}
\hline & $\begin{array}{l}P_{a} O_{2} \\
(m m H g)\end{array}$ & $\begin{array}{l}\mathrm{P}_{a} \mathrm{CO}_{2} \\
(\mathrm{mmHg})\end{array}$ & $\mathrm{p} H$ & $\begin{array}{l}S_{a} O_{2} \\
(\%)\end{array}$ & $\begin{array}{l}\mathrm{C}_{a} \mathrm{O}_{2} \\
(\text { vol \%) }\end{array}$ & $\begin{array}{l}\mathrm{CvO}_{2} \\
(\text { vol \%) }\end{array}$ & $\begin{array}{l}\mathrm{AV} \mathrm{O}_{2} \\
\text { difference } \\
(\text { vol } \%)\end{array}$ \\
\hline $\begin{array}{l}\text { Control } \\
\text { I0 } \mathrm{mg} \\
\text { P } \\
20 \mathrm{mg} \\
\mathrm{P}\end{array}$ & $\begin{array}{l}60 \cdot 7 \pm 2 \cdot 2 \\
62 \cdot 0 \pm 2 \cdot 3 \\
N S \\
65 \cdot 0 \pm 2 \cdot 5 \\
P<0 \cdot 01\end{array}$ & $\begin{array}{l}37 \cdot 0 \pm 1 \cdot 0 \\
35 \cdot 5 \pm 1 \cdot 1 \\
\mathrm{NS} \\
34 \cdot 8 \pm 1 \cdot 1 \\
\mathrm{NS}\end{array}$ & $\begin{array}{l}7.43 \pm 0.01 \\
7.43 \pm 0.01 \\
\text { NS } \\
7.43 \pm 0.01 \\
\text { NS }\end{array}$ & $\begin{array}{l}90 \cdot 0 \pm 0.9 \\
90 \cdot 5 \pm 0.8 \\
\mathrm{NS} \\
9 \mathrm{I} \cdot \mathrm{I} \pm 0.7 \\
\mathrm{NS}\end{array}$ & $\begin{array}{l}16.85 \pm 0.7 \\
16.91 \pm 0.66 \\
N S \\
16.73 \pm 0.6 \\
N S\end{array}$ & $\begin{array}{l}\text { I I } .98 \pm 0.7 \\
\text { I I. } 2 \pm 0.6 \\
P<0.01 \\
\text { I0.67 } \pm 0.6 \\
P<0.001\end{array}$ & $\begin{array}{l}4.87 \pm 0.34 \\
5.72 \pm 0.45 \\
P<0.001 \\
6.06 \pm 0.43 \\
P<0.001\end{array}$ \\
\hline
\end{tabular}

$\mathrm{P}_{a} \mathrm{O}_{2}=$ oxygen tension; $\mathrm{P}_{a} \mathrm{CO}_{2}=$ carbon dioxide tension of arterial blood; $\mathrm{C}_{a} \mathrm{O}_{2}$ and $\mathrm{CvO}_{2}=$ oxygen content of arterial and mixed venous blood.

figure, $\left.2 \cdot 46 \pm 0 \cdot 141 . / \mathrm{min} / \mathrm{m}^{2}\right)$. This reduction in cardiac output was linked solely to the fall in heart rate since the stroke index did not vary (control value: $35 \cdot 3 \pm 2 \cdot 4$; after practolol : $34 \cdot 4 \pm 2 \cdot 0$ and $34 \cdot 2 \pm 2 \cdot 2 \mathrm{ml} /$ beat $\left./ \mathrm{m}^{2}\right)$. The ejection time was lengthened moderately from $0.263 \pm 0.014 \mathrm{sec}$ to $0.270 \pm 0.013 \mathrm{sec}$, though this increase was not statistically significant. The mean pulmonary arterial pressure which was slightly raised during the control period $(2 \mathrm{I} \cdot 0 \pm \mathrm{I} \cdot 9 \mathrm{mmHg})$ was not affected by either 10 $\mathrm{mg}$ or $20 \mathrm{mg}$ practolol $(2 \mathrm{I} \cdot 6 \pm 2 \cdot 4$ and $21 \cdot 0 \pm \mathrm{I} \cdot 9 \mathrm{mmHg})$. The mean, diastolic, and systolic aortic pressures fell insignificantly. Peripheral arterial and pulmonary arterial resistances were unchanged by either 10 $\mathrm{mg}$ or $20 \mathrm{mg}$ practolol (Fig. 2).

The stroke work index was reduced only

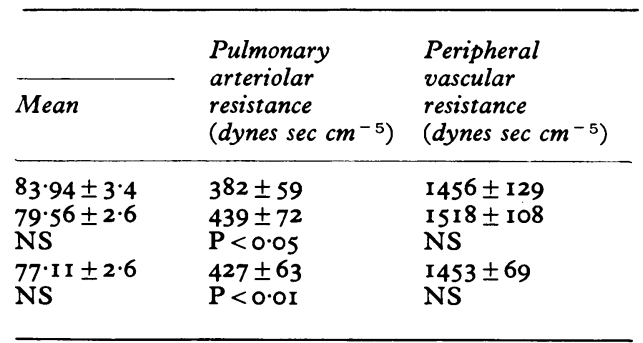

TABLE 4 Blood gases in coronary sinus blood and arterial blood (5 patients)

\begin{tabular}{lccc}
\hline & Control & $10 \mathrm{mg}$ & $20 \mathrm{mg}$ \\
\hline $\mathrm{P}_{s c} \mathrm{O}_{2}(\mathrm{mmHg})$ & $24 \cdot 5 \pm \mathrm{I} \cdot 9$ & $26 \cdot 3 \pm 2 \cdot 3$ & $25 \cdot 0 \pm \mathrm{I} \cdot \mathrm{I}$ \\
$\mathrm{S}_{s c} \mathrm{O}_{2}(\%)$ & $28 \cdot 8 \pm 2 \cdot 7$ & $29 \cdot 5 \pm 3 \cdot 0$ & $28 \cdot 6 \pm 2 \cdot 7$ \\
$\mathrm{C}_{s c} \mathrm{O}_{2}(\%)$ & $7 \cdot 02 \pm 0.6$ & $7 \cdot 16 \pm 0.6$ & $7 \cdot 6 \pm 0.5$ \\
$\mathrm{C}_{a} \mathrm{O}_{2}($ vol \%) & $17 \cdot 30 \pm 0.50$ & $17 \cdot 79 \pm \mathrm{I} \cdot 0$ & $17 \cdot 86 \pm \mathrm{I} \cdot \mathrm{I}$ \\
$\begin{array}{l}\text { Coronary AV } \\
\mathrm{O}_{2}(\text { vol \%) } \\
\text { difference }\end{array}$ & $10.28 \pm 0.8$ & $10.63 \pm \mathrm{I} \cdot \mathrm{I}$ & $10.80 \pm \mathrm{I} \cdot 0$
\end{tabular}

$\mathrm{P}_{s c} \mathrm{O}_{2}, \mathrm{~S}_{s c} \mathrm{O}_{2}, \mathrm{C}_{s c} \mathrm{O}_{2}=$ oxygen tension, saturation, and content of coronary sinus blood.

very slightly and to an insignificant extent (Fig. 3) while the external work index clearly fell from $4240 \mathrm{~g} \mathrm{~m} / \mathrm{min} / \mathrm{m}^{2}$ to $3640 \mathrm{~g} \mathrm{~m} / \mathrm{min} /$ $\mathrm{m}^{2}(\mathbf{P}<0.01)$. There was no further reduction after $20 \mathrm{mg}$. The systolic ejection rate was not altered since the stroke index and the systolic ejection time remained unchanged. The maximum first derivative of aortic pressure (dp/dt Ao) (Fig. 3) fell significantly from $905 \pm 88$ to $818 \pm 82 \mathrm{mmHg} / \mathrm{sec}(\mathrm{P}<0.05)$. A statistically significant correlation was found between the percentage fall in heart rate and the percentage lowering of aortic $\mathrm{dp} / \mathrm{dt}$ $(\mathbf{r}=0.59)$.

The tension time index per beat remained unchanged after administration of both ro $\mathrm{mg}$ and $20 \mathrm{mg}$ practolol (Fig. 4). By contrast, 
the tension time index per minute fell from $2307 \pm 142$ to $2094 \pm 113 \mathrm{mmHg} \mathrm{sec} / \mathrm{min}$ $(\mathrm{P}<0.05)$. No further reduction was observed after the administration of $20 \mathrm{mg}$ practolol (final value $1987 \pm 88 \mathrm{mmHg} \mathrm{sec} / \mathrm{min}$ ).

The arterial oxygen partial pressure did not change after ro mg practolol (Table 3 ) though it increased perceptibly and significantly $(\mathrm{P}<0.0 \mathrm{I})$ after $20 \mathrm{mg}$ practolol. The arterial carbon dioxide pressure and the $p \mathrm{H}$ were not altered. The oxygen content of arterial blood showed no change after $10 \mathrm{mg}$ and $20 \mathrm{mg}$ (Table 3). By contrast, the pulmonary arterial oxygen content $\left(\mathrm{CvO}_{2}\right)$ fell conspicuously after $10 \mathrm{mg}$ and $20 \mathrm{mg}(\mathrm{P}<0.01)$. This gave rise to a significant increase in the arteriovenous difference from $4.92 \pm 0.34$ to $5.78 \pm$ 0.45 and to $6.05 \pm 0.3$ vol per cent $(P<0.001)$.

Gases in the coronary venous blood (Table 4) did not show any significant change. The coronary arteriovenous difference did not increase.

\section{Discussion}

The principal cardiovascular response to intravenous administration of 10 and $20 \mathrm{mg}$ practolol in the 18 patients studied was a reduction in heart rate. This slowing of the heart rate alone was responsible for the moderate decrease in cardiac output. Jewitt, Burgess, and Shillingford (1970) made similar observations at comparable dosage levels. As oxygen consumption calculated indirectly from cardiac output and the arteriovenous oxygen difference was not significantly reduced, the fall in cardiac output was compensated by a proportionate increase in the arteriovenous oxygen difference, at the expense of the saturation of mixed venous blood. The ejection time was lengthened to an insignificant extent. Jewitt et al. (1970) reported a significant increase in ejection time. The difference between these two results probably stems from the fact that some of the patients studied by these authors had an increased stroke volume.

It is worth while pointing out that the pulmonary arterial pressure did not increase. Sowton et al. (1968) made an identical observation in patients suffering from coronary heart disease. In the group of patients studied by Jewitt et al. (1970) pulmonary arterial pressure rose by a few mmHg. Since none of the patients studied in this trial was suffering from chronic respiratory disease, the pulmonary arterial diastolic pressure provides an accurate index for the filling pressure of the left heart. Bussmann et al. (1970) administered doses of $2 \mathrm{mg} / \mathrm{kg}$ to dogs and did not
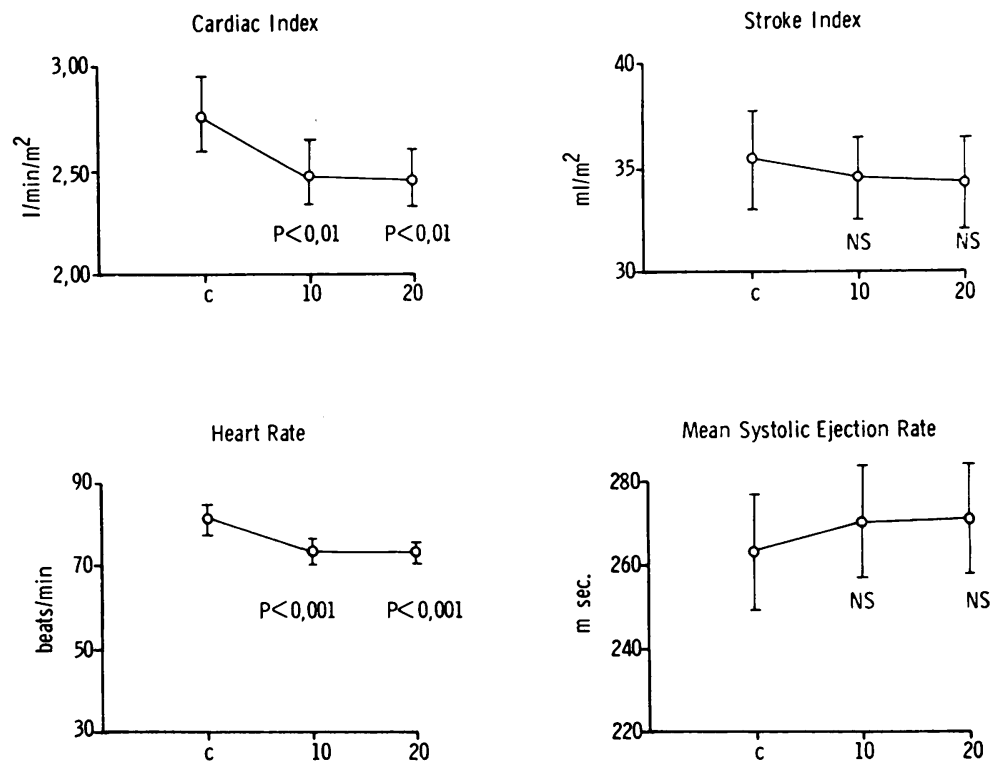

FIG. I Effect of intravenous injection of practolol on cardiac index, stroke index, heart rate, and mean systolic ejection rate (mean + $S E M), C$ : control, 10 and 20 : after 10 and $20 \mathrm{mg}$. respectively

FIG. 2 Effect of practolol on pulmonary arterial pressure, aortic pressure, and resistances. Ps : systolic pressure; $\mathrm{Pm}$ : mean pressure; $P d$ : diastolic pressure

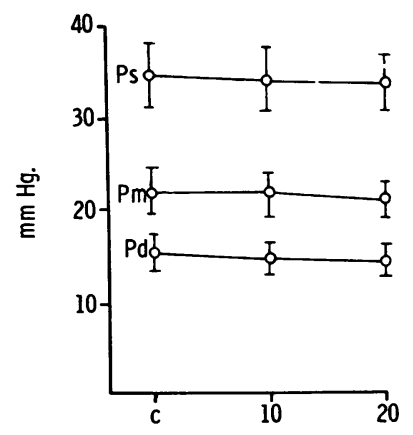

Puimonary Arterial Pressure
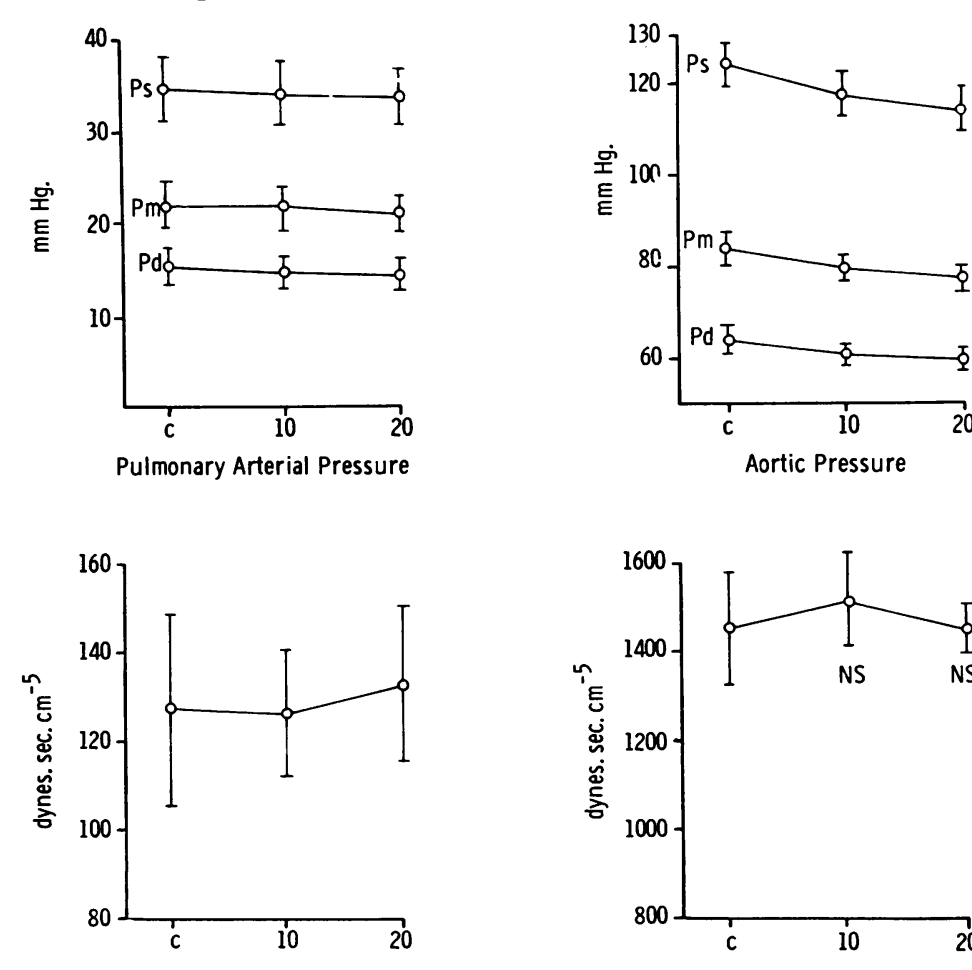

Pulmonary Arteriolar Resistance

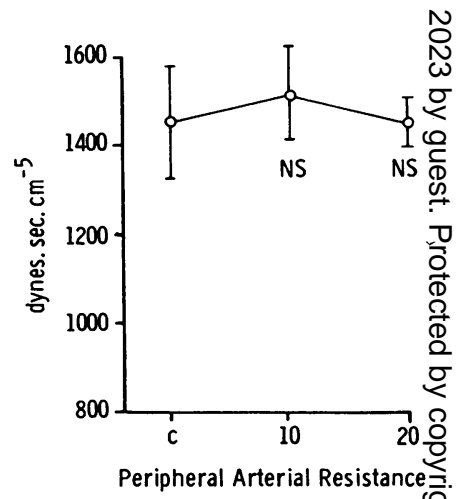

Peripheral Arterial Resistance 
record an increase in left ventricular enddiastolic pressure. Gibson et al. (1970), on the other hand, found a reduction of enddiastolic pressure in 7 patients with valve incompetence. In the present work, the constancy of the pulmonary arterial diastolic pressure suggests that the left ventricular enddiastolic volume did not increase and this is in agreement with the experimental studies of Bussmann et al. (1970) who measured ventricular volume by $a$ thermodilution technique.

At the doses used the reduction in contractility and myocardial oxygen consumption appears to result principally from the fall in heart rate. In fact, neither the stroke index nor the tension-time index per beat were decreased, but the external work index and the tension-time index per minute fell clearly. A reduction in myocardial $\mathrm{O}_{2}$ consumption could be inferred from this. However, this deduction does not take into account the velocity of contraction of the myocardial fibres which has been shown to be a major determinant of myocardial $\mathrm{O}_{2}$ consumption (Sonnenblick et al., 1965b). In both this haemodynamic study and that of Jewitt et al. (1970) the ejection rate, which is taken to reflect the rate of shortening, did not vary. However, the variations in the ejection rate do not always arise in the same way as those in the velocity of contraction. Sonnenblick et al. (1965a) observed that during adrenergic blockade the ejection rate increased even though the shift of the force-velocity curve indicated a reduction in contractility. The lowering of peak aortic dp/dt confirmed the negative inotropic effect of practolol. Nevertheless, this parameter, which varies in the same way as heart rate, did not permit one to determine whether the reduction in contractility arose solely from a fall in heart rate. Bussmann et al. (1970) have shown that in dogs, at least at doses of $2 \mathrm{mg} / \mathrm{kg}$, and when the heart rate was held constant, left ventricular peak dp/dt was lowered, $\mathrm{t}-\mathrm{dp} / \mathrm{dt}$ increased, and the ratio between the LV dp/dt and the integrated isovolumetric pressure diminished, both known to reflect accurately the inotropic state of the myocardium (Siegel et al., 1964).

After the injection of $20 \mathrm{mg}$ practolol the partial pressure of oxygen in the peripheral arterial blood increased slightly but significantly. This was an unexpected finding after beta-adrenergic blockade. It has been shown that practolol did not appreciably reduce, and might even increase $\mathrm{FEV}_{1}$ and that airway resistance was only slightly increased (MacDonald and McNeill, I968; Powles, Shinebourne, and Hamer, 1969). Furthermore, it
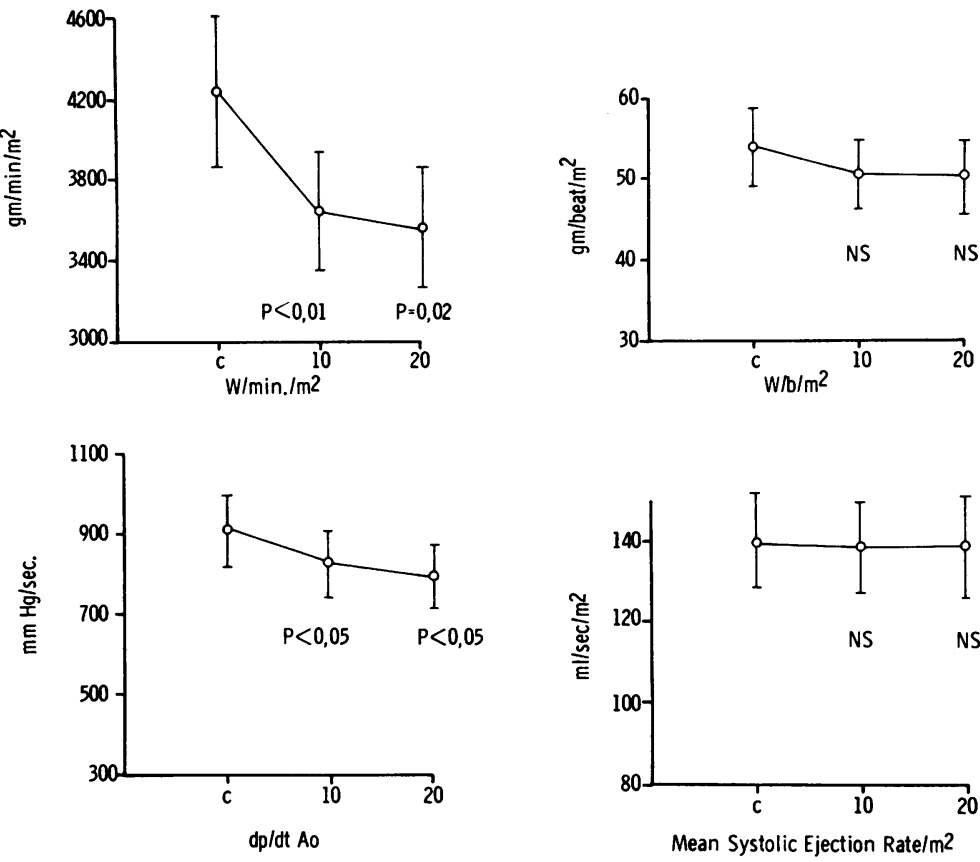

FIG. 3 Effect of practolol on external work index, stroke work index, aortic $d p / d t$, and mean systolic ejection rate per minute

has been shown that this drug inhibits the reduction in arterial $\mathrm{O}_{2}$ tension which can be observed after administration of isoprenaline to asthmatic patients (Palmer et al., 1969).

The coronary arteriovenous $\mathrm{O}_{2}$ difference in 5 patients where it could be measured was not increased. In this respect practolol had the same effect as propranolol, since Lewis and Brink (1968) noted that the coronary arteriovenous $\mathrm{O}_{2}$ difference increased no more than by 2 per cent; Mendel and Byrne-Quinn (I966) also observed that the saturation of coronary venous blood was not reduced after administration of propranolol. In contrast to other beta-blocking agents, practolol does not

FIG. 4 Effect of practolol on tension-time index
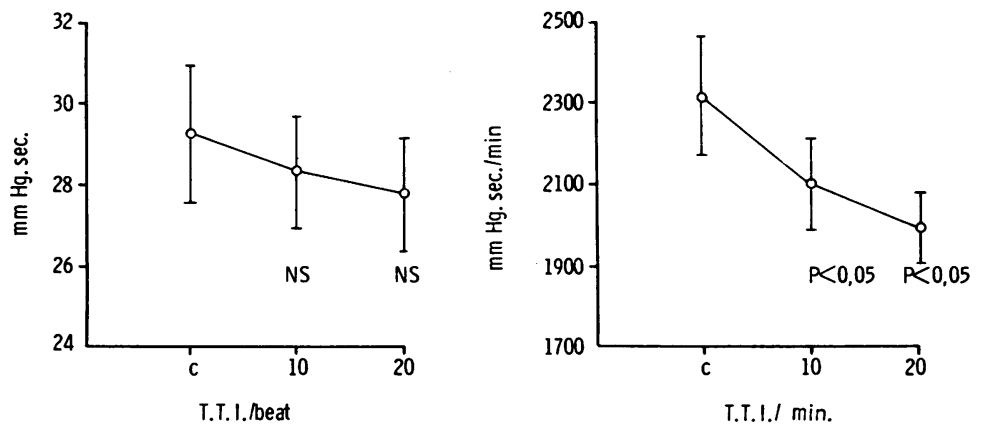
suppress coronary vasodilatation at dosage levels where it blocks the chronotropic and inotropic effects of isoprenaline (Ross and Jorgensen, I970). Bussmann et al. (1970) have found that, at high doses, practolol increases coronary flow and reduces the coronary arteriovenous $\mathrm{O}_{2}$ difference, though Ross and Jorgensen (I97I) and Barrett (I97I) have not been able to demonstrate this. Finally, even though the left ventricular diastolic volume was not increased, the fall in $\mathrm{O}_{2}$ consumption resulting from the reduction in heart rate and/or contractility was not, for the most part, counteracted by the increase in the ventricular wall tension, according to Laplace's law.

The results obtained from this study have revealed the important difference between the effects of practolol and propranolol. In patients suffering from a myocardial infarction Bay et al. (1967) found that $5 \mathrm{mg}$ propranolol reduced heart rate by 19 per cent, lowered cardiac output by 29 per cent, and increased peripheral vascular resistance by 40 per cent. Furthermore, the arterial pressure fell, the central venous pressure rose, and 3 of the 7 patients deteriorated clinically. If, pharmacologically, practolol is 3 to 4 times less active than propranolol, it is logical to state that, even at a dose of $20 \mathrm{mg}$, practolol only elicits a moderate decrease in cardiac output without reducing the stroke volume and the arterial pressure. At this dose it did not appear to influence the left ventricular end-diastolic volume nor to have any untoward effect on the coronary circulation.

This study provides evidence that practolol essentially had a negative chronotropic effect and that the reduction in contractility observed arose, for the most part, from a slowing in heart rate. An exact estimation of these effects may only be obtained from a further series of measurements made at constant heart rate.

The antiarrhythmic properties of practolol, especially on those rhythmic disturbances associated with adrenergic hyperactivity, demonstrate the undeniable therapeutic potential of the drug in acute myocardial infarction. The recent studies by Jewitt et al. (1969), Vohra, Dowling, and Sloman (1970), and Allen, Pantridge, and Shanks (I97I) support this view.

\section{References}

Ahlquist, R. P. (1948). A study of the adrenotropic receptors. American fournal of Physiology, 153, 586.

Allen, J. D., Pantridge, J. F., and Shanks, R. G. (197I). Practolol in the treatment of ventricular dysrhythmias in acute myocardial infarction. Postgraduate Medical Fournal, 47, Suppl. I, 29.
Barrett, A. M. (1971). The pharmacology of practolol. Postgraduate Medical fournal, 47, Suppl. I, 7.

Bay, G., Lund-Larsen, P., Lorentsen, E., and Siverstssen, E. (1967). Haemodynamic effects of propranolol (Inderol) in acute myocardial infarction. British Medical fournal, r, 141.

Bussmann, W. D., Rauh, M., and Krayenbuehl, H. P. (1970). Coronary and haemodynamic effects of myocardio-selective beta-receptor blockade by ICI 50172 in the closed-chest dog. American Heart Fournal, 79, 347.

Ceremuzynski, L., Staszewska-Barczak, J., and Herbaczynska-Cedro, K. (1969). Cardiac rhythm disturbance and the release of catecholamines after acute coronary occlusion in dogs. Cardiovascular Research, 3, 190.

Dunlop, D., and Shanks, R. G. (1968). Selective blockade of adrenoceptive beta-receptors in the heart. British fournal of Pharmacology and Chemotherapy, 32, 201.

George, M., Taylor, S. H., and Ramsay, J. A. (1967). Measurement of the maximum rate of rise of aortic blood pressure in man. Medical Research Engineering, 6, No. 4, 21.

Gibson, D. G., Hoy, J., and Sowton, E. (1970). Comparison of haemodynamic effects of oxprenolol (trasicor), alprenolol (aptin) and sotalol (MJ. 1999) in man (abstract). British Heart fournal, 32, 553.

Han, J. (1969). Mechanisms of ventricular arrhythmias associated with myocardial infarction. American fournal of Cardiology, 24, 800.

Jewitt, D. E., Burgess, P. A., and Shillingford, J. P. (1970). The circulatory effects of practolol (ICI 50172 ) in patients with acute myocardial infarction. Cardiovascular Research, 4, 188.

Jewitt, D. E., Mercer, C. J., and Shillingford, J. P. (1969). Practolol in the treatment of cardiac dysrhythmias due to acute myocardial infarction. Lancet, 2, 227.

Lands, A. M., Arnold, A., McAuliff, J. P., Luduena, F. P., and Brown, T. G. (1967). Differentiation of receptor systems activated by sympathomimetic amines. Nature (London), 214, 597.

Lewis, C. M., and Brink, A. J. (1968). Beta-adrenergic blockade: hemodynamics and myocardial energy metabolism in patients with ischemic heart disease. American fournal of Cardiology, 21, 846.

MacDonald, A. G., and McNeill, R. S. (1968). A comparison of the effect on airway resistance of a new beta blocking drug (ICI 50172 ) and propranolol. British fournal of Anaesthesia, 40, 508.

Mendel, D., and Byrne-Quinn, E. (1966). Effect of propranolol. Lancet, 2, 1026.

Palmer, K. N. V., Legge, J. S., Hamilton, W. F. D., and Diament, M. L. (1969). Effect of a selective beta-adrenergic blocker in preventing falls in arterial oxygen tension following isoprenaline in asthmatic subjects. Lancet, 2, 1092.

Parratt, J. R., and Wadsworth, R. M. (I969). The effect of 'selective' beta receptor blocking drugs on the myocardial circulation. British fournal of Pharmacology, 37, 52.

Parratt, J. R., and Wadsworth, R. M. (1970). The effect of 'selective' beta adrenoreceptor blocking drugs on the myocardial circulation. British fournal of Pharmacology, 39, 296.

Powles, R., Shinebourne, E., and Hamer, J. (1969). Selective cardiac sympathetic blockade as an adjunct to bronchodilator therapy. Thorax, 24, 616 .

Richardson, J. A. (1963). Circulating levels of catecholamines in acute myocardial infarction and angina pectoris. Progress in Cardiovascular Diseases, 6, 56 . 
Ross, G., and Jorgensen, C. R. (1970). Effects of a cardio-selective beta-adrenergic blocking agent on the heart and coronary circulation. Cardiovascular Research, 4, 148.

Ross, G., and Jorgensen, C. R. (197I). Effects of practolol on the coronary circulation. Postgraduate Medical fournal, 47, Suppl. I, 22.

Siegel, J. H., Sonnenblick, E. H., Judge, R. D., and Wilson, W. S. (1964). The quantification of myocardial contractility in dog and man. Cardiologia, 45, 189.

Sonnenblick, E. H., Braunwald, E., Williams, J. F., Jr., and Glick, G. (1965a). Effects of exercise on myocardial force-velocity relations in intact unanaesthetised man: relative roles of changes in heart rate, sympathetic activity, and ventricular dimensions. Fournal of Clinical Investigation, 44, 2051 .
Sonnenblick, E. H., Ross, J., Covell, J. W., Kaiser, G. A., and Braunwald, E. (1965b). Velocity of contraction as a determinant of myocardial oxygen consumption. American fournal of Physiology, 209, 919.

Sowton, E., Balcon, R.; Cross, D., and Frick, H. (1968). Haemodynamic effects of ICI 50172 in patients with ischaemic heart disease. British Medical fournal, 1, 215.

Vohra, J. K., Dowling, J. T., and Sloman, G. (1970). Practolol (ICI 50172), a beta-adrenergic receptor blocking agent, in management of cardiac arrhythmias. Medical fournal of Australia, 2, 228.

Requests for reprints to Dr. J.-P. Bourdarias, Hôpital Ambroise-Paré, 9 Avenue Charles de Gaulle, 92-Boulogne, France. 